\title{
URGENSI PENDOKUMENTASIAN PUTUSAN PERADILAN ADAT
}

\section{Oleh :}

\section{Gelar Sumbogo Peni}

\begin{abstract}
Abstrak
Penyelesaian kasus hukum dewasa ini menjadi perdebatan yang serius, rasa keadilan yang diharapkan oleh setiap warga negara yang memerlukan haknya, dijaman sekarang ini, begitu susahnya untuk mendapatkan rasa "adil". Praktik-prakti yang melukai untuk mendapatkan rasa adil, begitu menggurita, hampir di semua lini dan sendi-sendi penegak hukum setidaknya terkait dengan hal-hal yang mencederai keadilan itu sendiri.

Ungkapan tajam kebawah dan tumpul ke atas, sampai menjadi pembicaraan disisi kehidupan warga. Kekecewaan terhadap baik hasil vonis ataupun proses peradilan sangat melukai hati dari pencari keadilan. Ungkapan ada uang maka sangat mudah untuk mengatur para oknum penegak hukum. Dalam rangka memberikan solusi terhadap kekecewaan terhadap mekanisme dan juga praktik-praktik tidak jujur di lingkungan penegak hukum, bangsa Indonesia masih mempunyai warisan adiluhung yang dapat memberikan solusi dibidang peradilan.

Sistem peradilan adat yang merupakan jati diri, kepribadian bangsa Indonesia yang menempatkan nilai-nilai keadilan, musyawarah, mufakat, saling menghormati dan tidak terlepas dari keseimbangan antara manusia dengan sesama, keseimbangan hubungan manusia dengan sesama ciptaan Tuhan (Alam Semesta) dan juga mengharmoniskan hubungan manusia dengan Pencipta, telah diwariskan oleh para leluhur bangsa ini, adat tradisi yang begitu luhur dan berbudaya tinggi telah kita pandang sebelah mata, kita justru mengagungkan produ-produk lain yang belum tentu sesuai dengan cultur budaya kita.
\end{abstract}

Kata Kunci : Urgensi, Dokumentasi, Peradilan adat.

*Dosen pada Fakultas Dharma Sastra IAHN-TP Palangka Raya 


\section{PENDAHULUAN}

Sejak sebelum berdirinya Negara Kesatuan Republik Indonesia, nenek moyang kita sudah mengenal yang namanya norma atau aturan dalam tata kehidupan sosial masyarakat. Aturan atau norma ini cenderung mempunyai karakter dan ciri tersendiri dalam suatu lingkup pergaulan sosial masyarakat. Hal ini terjadi karena adanya kelompok warga yang hidup dalam suatu wilayah adat yang berbeda-beda, baik dari segi tempat, pergaulan atau etika hidup dan juga liedher ship atau kepemimpinan adat yang berdaulat atas suatu teretorial adat tertentu. Semua putusan, atau hal yang berkaitan dengan pemimpin sangat dihormati, ditaati, dan juga dijunjung tinggi oleh para warganya. Karena sebagian besar dari kalangan warga mempunyai interprestasi bahwa pemimpin itu adalah manifestasi dari Tuhan.

Oleh karena itu, wajar jika apapun putusan, perintah dari pemimpin sangatlah dijunjung tinggi, sebab sebagai konsekwensi jika tidak melaksanakan atau menolak perintah pemimpin, maka sebagian besar masyarakat akan mengganggab ia berdosa, dan akan mempunyai akibat hukum tersendiri. Jika mengabaikan tentang "dosa" ketika menolak atau tidak melaksanakan perintah penguasa, maka pemimpin bisa memberikan sanksi sebagaimana dia inginkan, tanpa perlu mempertimbangkan hal-hal yang dianggab meringkankan ataupun memberatkan bagi pelanggar tersebut. Karena pemimpin mempunyai kekuaasaan yang mutlak dan absolut, harus dipatuhi agar tidak ditiru dan memberikan (efek jera) kepada warga yang lain.

Seiring dengan perjalanan waktu dan sejarah, dimana wilayah nusantara dijajah oleh bangsa-bangsa Eropa, untuk menguasai harta kekayaan yang berlimpah, dan dengan mengadakan perlawananuntuk melepaskan diri dari cengkeraman penjajah yang dilakukan secara kedaerahan, tidak membuahkan hasil maka, ada inisiatif berjuang melawan penjajah secara global dengan mengadakan Gerakan Sumpah Pemuda 28 Oktober 1928. Di era ini, rasa dan sifat kedaerahan mulai muncul, hal ini 
semata-mata karena ingin melawan penjajahan. Puncaknya pada tanggal 17 Agustus 1945, Indonesia merdeka. Dengan merdekanya Negara Kesatuan Negara Republik Indonesia, maka dengan sendirinya segala konstitusi, wilayah dan warga juga menjadi satu. Wilayah-wilayah kesatuan adat juga melebur menjadi satu dibawah naungan Negara Kesatuan Republik Indonesia.

Namun semua perjalanan sejarah tidaklah secepat kilat, perlu waktu dan proses. Meskipun Negara telah ada, bukan berarti Negara hadir dalam kehidupan berbangsa dan bernegara, hak-hak sebagai warga negara belum semua terlayani, semua masih memerlukan proses. Begitu pula halnya dengan kepentingan warga negara dalam bidang keadilan dan layanan kepentingan penyelesaian sengketa baik sengketa perdata maupun pidana diantara warga negara, dengan tidak hadirnya negara dalam bidang tersebut, maka proses peradilan masih menggunakan peradilan adat. Sampai di era sekarang tahun 2019 ini keberadaan atau eksistensi Hukum Adat masih ditemukan di beberapa wilayah di Negara Kesatuan Republik Indonesia.

Keadaan sekarang lebih menyedihkan lagi, karena dalam beberapa sejak Negara Indonesia berdiri diera Orde Baru, dan Orde Reformasi hingga kini, sistem peradilan tidak lagi memberikan rasa keadilan bagi warga Negara. Kehakiman, Kejaksaan dan Kepolisian sebagai tempat pencari keadilan resmi milik Negara, keberadaannya seperti pasar tempat jual dan beli/negosiasi pasal-pasal untuk menyuburkan praktik-prakti korupsi, meskipun itu oknum tapi mewabah kesana-kemari. Tidak lagi melayani rasa adil yang berkeadilan bagi rakyat, tapi hanya rasa menang bagi mereka yang punya uang, walaupun tidak benar. Masyarakat sudah mulai putus asa, tidak lagi percaya dengan lembaga-lembaga tersebut diatas. Bahkan ada juga ungkapan "hukum hanya tajam kebawah, dan tumpul kebawah".

Dengan realitas hukum dinegeri ini, maka mulailah masyarakat mencari solusi untuk mendapatkan keadilan, mengharapkan lembaga pemerintah kredibilatasnya patut diragukan. Maka salah satu alternative 
yang dalam dilakukan adalah menggali kepada identitas jati diri bangsa Indonesia. Dengan cara menyelesaikan sengketa baik pidana maupun perdata diluar sistem peradilan nasional. Merunut dari latar belakang diatas, maka permasalahan yang ada dan diangkat adalah :

1. Bagaimanakah eksistensi Hukum Adat di Negara Kesatuan Republik Indonesia?

2. Bagaimana Cara Peradilan Adat dalam menyelesaikan sengketa ?

3. Bagaimana upaya untuk memperkuat putusan hasil sidang adat agar dapat dibuktikan Legal Formalnya?

\section{PEMBAHASAN}

\section{Eksistensi Hukum Adat di Negara Kesatuan Republik Indonesia}

Negara Indonesia, meskipun telah merdeka selama 74 tahun, tetapi dalam hal pelayanan masyarakat khususnya dibidang hukum belumlah maksimal, hal ini terjadi karena banyak faktor, diantaranya : luas wilayah geografi negara, pembangunan infrastruktur yang lambat, sumber daya manusia yang tidak merata, anggaran pembangunan reformasi hukum yang belum maksimal dan banyak lagi faktor lainnya. Keadaan letak geografis Indonesia yang luas, dan persebaran tempat penduduk yang tidak terkonsentrasi dan masih banyak masyarakat yang hidupnya terisolasi membuat segala yang bertalian dengan kehidupan luar sangat jarang dilakukan.

Hal ini bisa dimaklumi mengingat dengan keterisolasian kehidupan mereka, membuat sumber daya manusia khususnya di bidang pendidikan sangat rendah, tingkat pendapatan (ekonomi juga rendah), jalan darat tidak ada, fasilitas transportasi juga tidak ada. Hal inilah yang membuat masyarakat yang terisolir tersebut tidak mau menyelesaikan kasus atau sengketa yang menimpanya. Mereka perlu biaya mahal untuk mendapatkan layanan peradilan yang dilakukan oleh pemerintah, selain biaya mahal mereka juga merasa kehilangan banyak waktu. Yang mestinya bias digunakan untuk bekerja mencari sesuapnasi, tetapi tidak dapat dilakukan karena habis waktu untuk menyelesaikan sengketa. Tidak jarang pula jika 
mendapatkan kesempatan untuk menyelesaikan sengketanya, bukan rasa keadilan yang didapat, melainkan sebaliknya.

Dengan berbagai pertimbangan baik biaya, waktu dan juga rasa keadilan yang didapat belum tentu berdasarkan kebenaran, maka kecenderungan masyarakat yang hidup terisolir, tetap berusaha dengan penyelesaian kasus sengketa baik pidana maupun perdata dengan melalui penyelesaian sengketa diluar peradilan adat. Hal ini banyak di jumpai di daerah-daerah yang memang keberadaannya sangat terisolir, belum lagi kehidupan masyarakat yang memang belum mendapatkan haknya sebagai warga Negara.

Masyarakat adat sering kita jumpai atau kita dengar di wilayah Indonesia bagian Timur : Papua, sebagian Sulawesi, Kalimantan, Sumatera bahkan daerah yang sudah maju pun ada yang masih menggunakan hukum adat, yaitu di Pulau Bali. Mereka tetap mengakui sebagai warga Negara Republik Indonesia tetapi dalam hal-hal tertentu, mereka tetap sebagai jati diri sebagai identitas social yang sangat dihormatinya. Mereka hidup di desa-desa adat atau wilayah adat tertentu. Sampai sekarang pun mereka tetap menjaga, melestarikan adat dan tradisi yang telah diwariskan oleh para leluhurnya. Keberadaan atau eksistensi Hukum Adat di Indonesia dapat kita lacak dan buktikan semisal : di Papua, ketika terjadi konflik antar suku atau konflik horizontal lainnya, maka penyelesaian yang paling tepat dan konkrit adalah bukan keberadaan aparat keamanan dengan Standar Prosedur Operasionalnya, melainkan kehadiran pemerintah dengan segala pendukungnya untuk memfasilitasi pertikaian itu dengan cara hukum mereka yang dinegosiasikan dan di putuskan. Jika hal ini dilakukan maka masyarakat yang bertikai akan lebih dapat menerima putusan tersebut.

Di Kalimantan begitu pula, jika ada konflik social maka masyarakat adat yang berkonflik difasilitasi perintah bersama jajarannya untuk membuat perdamaian sesuai dengan adat dan tradisi mereka, masih di Papua, jika ada Pemilu baik Pilihan Kepala Daerah ataupun Legeslatif yang mestinya bersifat individu, maka disana suara diserahkan sepenuhnya 
kepada Kepala Suku/Adat untuk mewakili warganya, begitu pula di pulau Bali, Pecalang sebagai penegak hukum adat selalu ada dan hadir dalam rangka menjalankan tugas-tugas yang dipercayakan oleh adat kepadanya. Dari beberapa contoh diatas dapat dikatakan bahwa keberadaan/eksistensi hukum adat masih ada dan berlaku di Indonesai. Tadi yang disebutkan hanyalah sebagian kecil dari tata kehidupan adat istiadat yang ada di wilayah Negara Republik Indonesia. Faktanya, hukum adat hingga sekarang keberadaannya ada dan masih hidup dalam masyarakat adat di Indonesia.

\section{Cara Peradilan Adat Dalam Menyelesaikan Sengketa}

Adat dan tradisi leluhur bangsa Indonesia sangatlah identik dengan musyawarah dan mufakat serta gotong royong, hal ini dibuktikan dengan nilai-nilai luhur yang digali dan dijadikan dasar oleh presiden pertama Republik Indonesia Ir. Sukarno, di implementasikan dalam pondasi rumah besar Negara Indonesia, yaitu Pancasila. Dimana nilai musyawarah dan mufakat serta gotong royong dimuat pada sila ke-empat dari lima sendi dasar kehidupan berbangsa dan bernegara.

Sengketa baik pidana ataupun perdata, selalu terjadi di setiap waktu, pemangku kekuasaan dalam hal ini kepala adat harus sesegera mungkin untuk menyelesaikan dengan seadil-adilnya, agar perselisihan segera berakhir dan kehidupan social masyarakat normal kembali. Mereka berpedoman pada hukum adat yang tidak tertulis atau berpedoman pada putusan yang telah pernah di jatuhkan sebelumnya dalam kasus yang sama (yurisprodensi). Dalam hal mekanisme, penyelesaian kasus diluar peradilan, maka pihak-pihak yang bersengketa atau salah satu pihak yang merasa dirugikan harus melaporkan terlebih dahulu kepada kepla adat

Setelah ada laporan, maka kepala adat akan berkoordinasi secara lisan dengan jajarannya dan juga para tokoh adat. Setelah berkoordinasi secara lisan maka akan disepakati kapan untuk mendamaikan sengketa tersebut. Setelah ditentukan hari " $\mathrm{H}$ ", maka kepala adat akan memberitahukan dan mengundang kepada pihak-pihak yang bersengketa untuk bertemu guna membicarakan sengketa diantara mereka yang didengarkankan dan 
disaksikan oleh pihak-pihak yang berkepentingan. Mulai dari sini, penyelesaian sidang adat itu berlangsung, suasana penuh dengan kekeluargaan, semua pihak yang bersengketa diberi kesempatan yang sama dalam hal menyampaikan keluhannya yang membuat dirinya merasa dirugikan.

Setelah dirasa cukup dalam penyampaian keluhannya, maka kepala adat akan memberikan kesempatan kepada tokoh masyarakat yang ada, jajaran pengurus lembaga adat yang ada, untuk menanggapi sengketa di antara mereka. Biasanya bukan hanya tanggaban saja yang diberikan, tetapi juga solusi, termasuk juga untung ruginya. Proses disini lama penyelesaianya memang tergantung kepada bobot kasus yang disengketan, kasus berat apa ringan, perlu bukti apa tidak, perlu saksi apa tidak dan lain sebagainya. Biasanya dalam kesempatan ini terjadi dialogis yang sepertinya non formal. Ada kalanya diselingi canda dan tawa juga bias saja terjadi.

Setelah keterangan didapat cukup, maka kepala adat akan mencari petunjuk tentang siapa yang bersalah berdasarkan hukum adat yang berlaku, atau berdiskusi dengan unsur adat dan tokoh masyarakat untuk menentukan siapa yang bersalah dalam hal ini, jika kasus tersebut belum pernah terjadi. Setelah mendengarkan dengan seksama, mencerna sengketa yang ada, mempertimbangkan berbagai masukan dari lembaga adat dan tokoh masyarakat, maka kepala adat akan menjadi penentu dalam memutuskan sengketa dimaksud. Dengan berbekal saran, masukan dan juga kemampuan kepala adat dalam berpikir, maka kepala adat akan memberikan putusan. Dalam hal ini putusan biasanya diambil dari hasil musyawarah tokoh-tokoh masyarakat dan adat.

Biasanya yang sering terjadi, setelah putusan disampaikan yang berdasarkan hukum adat, maka pihak-pihak yang bersengketa yang dinyatakan bersalah akan di beri sanksi denda, besar dan kecilnya tergantung pada kasusnya, setelah disampaikan putusan tersebut biasanya dilanjutkan dengan nasehat dari para tokoh adat dan juga dari lembaga adat, dilanjutkan lagi dengan saling bermaaf-maafan. Setelah itu maka akan 
ditanyakan kapan denda tersebut akan di bayarkan, setelah mendapat kepastian jawaban tentang denda dimaksud, maka penyelesaian sengketa dinyatakancukup, tapi belum selesai. Kasus tersebut dinyatakan selesai jika denda sudah dibayarkan, tujuan pembayaran denda adalah untuk mengumpulkan kembali masing-masing yang bersengketa, tokoh adat, tokoh masyarakat dan juga warga.

Kegunaan pembayaran denda dimaksud ditujukan untuk upacara ritual, menyeimbangkan kembali alam yang telah tercemar akibat perbuatan/kasus mereka, kemudian juga untuk mempersiapkan jamuan pada saat itu untuk warga yang hadir, serta memberi tahukan bahwa kedua orang yang bersengketa sudah didamaikan dan sudah kasusnya dianggab selesai. Acara terakhir adalah saling bermaafkan diantara mereka dan menganggab tidak pernah terjadi yang disaksikan oleh semua elemen warga. Dari kronologis ini dapat terlihat rasa adil, keiklasan, kebersamaan, saling menghormati, dan kewibawaan putusan yang dijatuhkan oleh kepala adat sangat dijunjung tinggi oleh warganya. Penyelesaian perkarapun tidak hanya melibatkan antara manusia, tetapi juga bertalian dengan alam dan juga Sang Pencipta.

\section{Upaya Untuk Memperkuat Putusan Hasil Sidang Adat Agar Dapat Dibuktikan Legal Formalnya}

Semakin lama diyakini apa tidak, bahwa tingkat pendidikan warga Negara semakin meningkat, hal ini terjadi karena perintah konstitusi guna mencerdaskan kehidupan bangsa, hal ini juga berdampak terhadap peradilan adat. Sebab selama ini hasil putusan adat, sangat langka sekali untuk mendapatkan bukti dokumen berupa putusan tertulis dalam penyelesaian suatu sengketa, tetapi anehnya walaupun tidak ada putusan yang terdokumentasikan, tetapi warga tetap mematuhi dan menjunjung tinggi putusan tersebut. Hal ini terjadi kemungkinan besar karena putusan kepala di beck up oleh warga adat, atau bias juga di katakana sanksi social, sehingga jika terjadi pengingkaran putusan, maka dia akan sangat merasa malu di masyarakat tersebut. 
Dengan semakin meningkatnya tingkat pendidikan warga, rupanya tidak terlalu berdampak arti "rasa malu". Mereka sekarang malah sibuk mencari dalil-dali, bukti-bukti atas sanksi yang telah dijatuhkan. Selain bukti dokumen memang dirasa sangat perlu meningkatkan sumber daya manusia khususnya kepala adat untuk dapat pendidikan, pelatihan, sosialisasi tentang pentingnya bukti dokumen putusan yang telah diambilnya, supaya para kepala adat terlindungi dari aksi-aksi yang mempunyai kepentingan dan melupakan kepribadian bangsa yang mempunyai jati diri.

Selain pentingnya administrasi atau dokumen, perlu juga kerang legalitas yang dikeluarkan oleh pemerintah daerah, ataupun pemerintah pusat sebagai pijalkan bagi para kepala adat dalam mengadministrasikan lembaga peradilannya.Apakah itu melalui peraturan daerah, keputusan ketua pengadilan atau dengan kesepakatan antara lembaga adat dengan aparat penegak hukum. Formalisasi lembaga adat ini akan mempengaruhi perubahan nilai dan tatacara dalam melaksanakan peradilan adat sebab telah mulai mengadopsi nilai-nilai dan tatacara peradilan formal. Hal ini dilakukan untuk menjamin peradilan adat mengikutistandar-standar yang umum dipakai oleh peradilan formal, misalkan berkaitan dengan asas praduga tak bersalah maupun persamaan dihadapan hukum equality before the law yang umum dikenal dalam praktik peradilan.

Upaya untuk melegalisasi lembaga peradilan adat terbuka pada inisiatitf perundang-undangan yang sedang berlangsung, misalkan dalam RUU Pengakuan dan Perlindungan Hak-hak Masyarakat Adat yang sekarang sedang disiapkan oleh Badan Legislasi DPR, atau dalam RUU Desa yang sedang dibahas pada Komisi II DPR. Selain pada level nasional, pada level daerah dapat didorong peraturan daerah, keputusan kepala daerah maupun kesepakatan-kesepakatan antara berbagai pihak, terutama antara lembaga adat dengan aparat penegak hukum untuk menggunakan peradilan adat sebagai bagian penting dalam upaya memudahkan akses masyarakat terhadap keadilan. 
Cara formalisasi lain yang dapat dilakukan bukan dengan melegalisasi struktur kelembagaan peradilan adat, tetapi melegalisasi putusan-putusan yang dikeluarkan oleh peradilan adat. Dengan pendekatan ini maka negara tidak perlu ambil pusing dengan struktur peradilan adat, termasuk tidak perlu pusing dengan berapa jumlah orang yang terlibat dalam peradilan, apakah pimpinan acara sidang dipimpin oleh orang yang disebut hakim atau dengan nama lokal. Inti dari pendekatan formal yang kedua ini lebih berorientasi pada hasil yang dibuat dari peradilan adat. Putusan peradilan adat tersebut kemudian dicatatatkan oleh seorang hakim keliling. Hakim keliling merupakan hakim muda yang ada di pengadilan negeri. Jadi, hakim muda harus datang bila ada sidang adat yang dilakukan di kampung-kampung.Cara ini juga memiliki kontribusi agar ikut 'mendidik' hakim muda ikut terlibat dengan hukum yang berlaku di dalam masyarakat. Hal ini dapat menjadi bekal dikemudian hari karena ada kewajiban kepada hakim untuk menggali nilai-nilai yang hidup di dalam masyarakat.

Cara ini memang belum dipraktikan di Indonesia, tetapi perlu diwacanakan dan dicoba. Kumpulan dari putusan tersebut dapat menjadi bahan bagi pengadilan bila ada pihak yang tidak puas dengan putusan peradilan adat dan datang pengadilan negeri. Pengadilan negeri yang mengadili perkara yang telah ditangani oleh peradilan adat dapat mengundang hakim-hakim peradilan adat untuk menjadi ahli di persidangan. Putusan-putusan peradilan adat dikumpulkan dalam sebuah dokumen yang menjadi bahan kajian kalangan akademisi. Dengan menjadikan bahan kajian oleh akademisi, maka diharapkan hukum adat akan lebih jauh berkembang karena menjadi persoalan yang diteliti dan didiskusikan.

\section{PENUTUP}

1. Eksistensi Hukum Adat di Negara Kesatuan Republik Indonesia sampai tahun 2019 ini masih ada dan juga masih diberkaukan diwilayah Negara Kesatuan Republik Indonesia, terutama didaerahdaerah yang terisolasi, mengingat luas geografis Negara yang begitu 
luas. Daerah-daerah tempat lembaga peradilan adat yang masih eksis adalah di Pulau Papua, Pulau Kalimantang, Pulau Sulawesi, sebagian Pulau Sumatera. Keberadaan Peradilan adat bukan hanya terdapat pada pulau-pulau yang terisolasi saja, di pulau Bali yang merupakan pulau megapolitan juga masih eksis peradilan adatnya juga kelembagaannya. Kelembagaan Peradilan Hukum Adat merupakan cerminan jati diri bangsa, melestarikan tradisi dan adat-istiadat yang telah diwariskan oleh leluhur bangsa.

2. Peradilan Adat dalam beracara pada saat menyelesaikan sengketa dijiwai oleh nilai-nilai luhur bangsa Indonesia yang telah mendarah daging bagi masyarakat Indonesia, dan diwariskan dari generasi kegenarasi berikutnya, warisan beracara dalam penyelesaian sengketa hasil karya leluhur bangsa Indonesia yang mencerminkan adat dan budaya yang tinggi, mengutamakan musyawarah dan mufakat, menjunjung tinggi nilai-nilai sopan-santun/etika, saling menghormati dan menghargai, yang merupakan ciri khas jati diri dan kepribadian bangsa Indonsia. Menghasilkan putusan yang menempatkan nilai, dan rasa adil, mendasarkan putusan pada terciptanya keharmonisan antara manusia dengan Penciptanya, Manusia dengan sesama manusia, juga antara manusia dengan sesama ciptaan Tuhan (alam semesta).

3. Dalam rangka mewujudkan kewibawaan putusan peradilan diluar pengadilan, untuk membuat dokumen putusan persidangan adat, maka perlu peningkatan kualitas sumber daya manusia, kepala adat dan jajarannya perlu ditingkatkan dengan penyelenggaraan, sosialisasi, pelatihan, diklat. Bagi pemerintah baik pemerintah kota/kabupaten, pemerintah Provinsi ataupun Pemerintah pusat untu membuat peraturan yang dapat dijadikan dasar oleh pemangku adat dalam melaksanakan kewajibannya. 


\section{DAFTAR PUSTAKA}

Emil Kleden, 2006. Peradilan Adat: Cermin upaya membangun otonomi. Majalah ForumKeadilan. No. 20, 10 September 2006

Hedar Laudjeng, 2003. Mempertimbangkan Peradilan Adat, Seri PengembanganWacana, Jakarta: HuMa.Hilman Hadikusuma, 1989. Peradilan Adat di Indonesia, Jakarta: CV Miswar.

Laurensius Gawing, 2006. Peradilan Adat: Keadilan yang ternafikan. Majalah ForumKeadilan : No. 21, 17 September 2006

Kelompok Kerja Akses terhadap Keadilan, 2009.

Strategi Nasional Akses Terhadap Keadilan, Jakarta: Bappenas.

Majelis Adat Aceh, tanpa tahun, Pedoman Peradilan Adat Aceh. Hal 8. Didownload dari : http://ind.adatjustice.org/wpcontent/uploads/pu blikasi/Buku\%20Pedoman\%20Peradilan.pdf Rifai Lubis, 2006. Menemukan yang hakiki dalam penyelesaian sengketa berbasis lokal,Majalah Forum Keadilan. No. 22, 24 September 2006 